\title{
PENTINGNYA PERAN PEKERJA SOSIAL DALAM LEMBAGA PENDIDIKAN
}

\author{
Oleh: \\ Dwi Putri Apriyan, Ishartono, \& Maulana Irfan \\ Email: \\ (kesosish@gmail.com; ishartonopeksos@gmail.com; sangirfan@gmail.com)
}

\begin{abstract}
Abstrak
Permasalahan di dalam lingkup pendidikan kini mulai bermunculan dikarenakan kenakalan remaja yang melanggar norma hukum. Salah satunya adalah tawuran remaja. Tindakan ini termasuk ke dalam tindakan kriminal, sebab telah banyak siswa yang menjadi korban dalam peristiwa ini. Perilaku menyimpang yang terjadi disebabkan oleh faktor internal yaitu yang berasal dari diri individu itu sendiri, dan faktor eksternal yaitu lingkup yang sering berhubungan dengan individu yaitu lingkungan sosialnya. Di dalam profesi pekerjaan sosial, ada salah satu cabang yang khusus memberikan pelayanan bagi para siswa disekolah, yaitu pekerja sosial di lembaga pendidikan (School Social Work). Dalam permasalahan ini, pekerja sosial memiliki peran penting dalam membantu menyelesaikan permasalahan yang dihadapi oleh remaja. Pihak sekolah bekerja sama dengan pekerja sosial untuk melakukan pendekatan terhadap pelajar untuk menanamkan nilai-nilai yang benar. Pelayanan pekerjaan sosial sebagai bagian dari program sekolah memberikan pertolongan terhadap anak-anak yang memiliki permasalahan sosial dan emosional yang menjadi penyebab kesulitan bagi mereka dalam penyesuaian di sekolahnya. Di negara maju, profesi ini sudah menjadi salah satu unsur dari sistem pendidikan. Tugasnya memberikan pelayanan konseling kepada para siswa yang mengalami problem, baik disekolah maupun di rumah. Namun sebaliknya, profesi pekerja sosial dalam bidang pendidikan belum cukup dikenal. Pekerjaan sosial sekolah perlu diakui eksistensinya oleh berbagai pihak yang berkepentingan dengan bidang pekerjaan sosial, utamanya pekerjaan sosial di dunia pendidikan. Peran pekerjaan sosial sekolah merupakan peran srategis yang penting ketika siswa menemui kendala-kendala dalam perkembangan sosialnya.
\end{abstract}

Keyword: pekerja sosial, eksistensi, school social work

\section{Pendahuluan}

Kenakalan remaja meliputi perilaku yang menyimpang dari norma-norma yang berlaku di masyarakat ataupun menyimpang dari norma-norma hukum. Perilaku tersebut akan berugikan dirinya sendiri dan orang-orang sekitarnya. Contoh kenakalan remaja yang melanggar hukum, salah satunya adalah permasalahan tawuran di kalangan pelajar semakin banyak, dampak dari tindakan tersebut mengakibatkan korban jiwa. Terjadinya tawuran pelajar sudah menjadi indikasi tindakan kriminal, karena tidak sedikit siswa yang membawa senjata tajam dan benda-benda lain yang membahayakan.

Hal ini pun tidak sepenuhnya kesalahan pihak pendidik. Perlu adanya analisis yang koprehensif untuk membuat kesimpulan. Berdasarkan perspektif pekerja sosial yang dikuti dalam website resmi Kemensos menuliskan bahwa, perilaku seseorang yang cenderung agresif dipengaruhi oleh faktor internal dan eksternal. Faktor internal berasal dari dalam diri remaja itu sendiri, yaitu adanya gangguan dari kepribadian dan mentalitas remaja. Sedangkan faktor eksternal berasal dari keluarga ataupun lingkungan sosial. (puslit.kemsos.go.id diakses 30/10/14 pukul 20.24 WIB) 
Kenakalan remaja dikategorikan kedalam perilaku menyimpang yang menimbulkan masalah sosial. Perilaku ini dapat dianggap sebagai sumber masalah kerena dapat membahayakan individu dan lingkungan sekitarnya. Dalam penanganannya, pekerja sosial ikut terlibat dalam menangani masalah sosial yang dilakukan remaja. Profesi ini ditempatkan di lembaga pendidikan dengan melakukan pendekatan secara personal kepada para pelajar yang melakukan kenakalan atau tindakan penyimpangan.

Pekerja sosial berupaya menciptakan hubungan yang seimbang atau serasi antara unsur-unsur yang ada di dalam sekolah seperti antara guru dan peserta didik, antara sekolah dan orang tua, antara sekolah dan lingkungan masyarakat, dan antara peserta didik dan orang tuanya.

Pelayanan pekerjaan sosial sebagai bagian dari program sekolah memberikan pertolongan terhadap anak-anak yang memiliki permasalahan sosial dan emosional yang menjadi penyebab kesulitan bagi mereka dalam penyesuaian di sekolahnya. Seperti yang dikutip dari buku Dasar-Dasar Pekerjaan Sosial, profesi pekerjaan sosial mempunyai tujuan, fungsi, serta kegiatan-kegiatan yang kadang-kadang tumpang tindih dengan profesi-profesi lainnya, yang juga bergerak dalam upaya pemberian bantuan kepada orang (Budhi Wibhawa, dkk. 2011. Hlm. 34).

\section{Kenakalan Remaja}

Menurut epistimologi kenakalan remaja adalah berarti suatu penyimpangan tingkah laku yang dilakuakan oleh remaja hingga mengganggu ketentraman diri sendiri dan orang lain. (Hasan Basri. 1996. Hlm.13). Hal ini dapat dilihat dari kejadian yang dilakukan oleh para siswa yang melakukan kenakalan.

Dampaknya akan dirasakan oleh pelaku dan orang disekitarrnya. Misalnya seperti ada siswa yang melakukan tawuran, maka yang menjadi korban pada saat itu adalah orang yang ada di sekitarnya. Sedangkan dampak dalam jangka panjangnya seperti hukuman sosial yang didapat oleh siswa yang melakukan kenalan tersebut. Menurut Sofyan Wilis kenakalan remaja terjadi karena dipengaruhi oleh beberapa faktor, diantaranya:

1. Faktor pada diri remaja sendiri.

a. Responding factor, faktor ini memberikan kecenderungan tertentu pada diri remaja. Faktor tersebut dibawa sejak lahir oleh remaja. Hal ini dapat berupa birth injury, yaitu luka dikepala ketika bayi ditarik dari perut ibu, faktor lainnya yaitu kelainan pada kejiwaan.

b. lemahnya pertahanan diri, faktor ini ada dalam diri remaja untuk mengontrol dan mempertahankan diri.

c. Kurangnya kemampuan penyesuaian diri, inti permasalahan nya pada ketidak mampuan penyesuaian diri dengan lingkungan sosial. Pada remaja kurang mempunyai daya pilih teman bergaul yang membantu pembentukan perilaku positif.

2. Penyebab kenakalan remaja yang disebabkan oleh lingkungan keluarga seperti kurangnya kasih sayang atau karena faktor ekonomi di dalam keluarga tersebut.

3. Penyebab kenakalan remaja yang disebabkan dari lingkungan masyarakat seperti remaja berada dilingkungan masyarakat yang kurang memperoleh pendidikan.

4. Penyebab kenakalan remaja yang berasal dari sekolah. (Sofyan Wilis. 2008. Hlm.93-118)

\section{Bentuk-Bentuk Kenakalan Remaja}

Kenakalan remaja yang dilakukan tidak hanya dari tindakan tawuran saja. Pekerja sosial yang berada di dalam lingkup sekolah harus mengetahui bentuk dari kenakalan remaja, untuk membantu memudahkan dalam melakukan intervensi. Ada beberapa bentuk kenakalan remaja menurut Sarlito Wirawan Sarwono, yaitu:

1. Kenakalan yang menimbulkan korban fisik pada orang seperti perkelahian, penganiayaan, pembunuhan, pemerkosaan dan lain-lain. 
2. Kenakalan yang menimbulkan korban materi, seperti perusakan, pemerasan, pencopetan, dan pencurian.

3. Kenakalan sosial yang tidak menimbulkan korban dipihak orang lain, seperti merokok, pelacuran, dan menyalahgunakan obat terlarang.

4. Kenakalan yang melawan status, misalnya pelajar yang menerobos, anak yang melawan orang tua, dan saudara yang saling bertengkat. (1994. Hlm.205)

\section{Peran Pekerja Sosial}

Pekerja sosial memiliki peran sentral dalam sistem pelayanan sosial. Secara garis besar, ada empat peran dalam profesi pekerjaan sosial diantaranya (Budhi Wibawa, dkk. 2010. Hlm.33-34):

1. Meningkatkan kapasitas orang dalam menangani masalah yang dihadapinya.

2. Menggali dan menghubungkan sumber-sumber yang tersedia disekitar klien.

3. Meningkatkan jaringan pelayanan sosial.

4. Mengoptimalkan keadilan sosial melalui pengembangan kebijakan.

Pekerja sosial melakukan proses pemberian bantuan terhadap klien. Hal ini berkaitan dengan masalah yang sedang dihadapi oleh klien untuk melihat kebutuhan kebutuhan klien dalam menyelesaikan masalah. Ada beberapa peran pekerja sosial menurut Parons, Jorgensen, dan Hernandez yang dikutip oleh Edi Suharto (2009) yaitu sebagai enabler atau fasilitator, broker, mediator, pendidik, dan konselor.

Pekerja sosial yang bekerja di dalam lembaga pendidikan menggunakan perannya sebagai pendidik dan konselor. Dalam perannya sebagai pendidik, pekerja sosial harus mampu memberikan pengetahuan dan keterampilan bagi klien agar dapat berfungsi secara sosial dan mampu memenuhi kebutuhan-kebutuhannya. Karena seperti yang dikutip dari Edi Suharto, sering kali klien keterbatasan akan pengetahuan dan keterampilan sehingga masuk kedalam kelompok yang rentan dalam menghadapi goncangan sosial. (Edi Suharto, hlm. 97-101). Sedangkan peran sebagai konselor tidak dapat begitu saja diperankan oleh siapa saja. Konseling yang dilakukan merupakan metode yang professional yang diperoleh dari pendidikan formal ataupun pengalaman yang telah teruji. Dalam hal ini seorang konselor di lingkungan pendidikan membantu pelajar yang terlibat tawuran agar menyadari kesalahan yang diperbuatnya.

\section{Pelayanan Pekerja Sosial Sekolah}

Pekerja sosial sekolah memainkan peranan penting dalam hubungan kapasitas antara sekolah dan agensi-agensi sosial masyarakat yang lain yang menolong sekolah dan sumber-sumber lainnya satu sama lain bermanfaat terhadap yang lainnya. Berikut ini adalah tugas dan tanggung jawab pekerja sosial di sekolah, menurut Costin $(1972 \cdot$ Hlm. 351):

1. Pekerja sosial harus mempermudah persyaratan bagi pendidikan langsung dan pelayanan sosial terhadap para siswa serta menyediakan pelayanan sosial langsung terhadap para siswa terpilih.

2. Pekerja sosial harus bertindak sebagai pengacara siswa, berfokus pada kebutuhan-kebutuhan yang penting dari kelompok siswa terpilih.

3. Pekerja sosial harus berkonsultasi dengan para administrator sekolah agar bersama-sama mengidentifikasi situasi permasalahan atau permasalahan yang kompleks yang mana pendekatan pelayanan direncanakan akan dituju, bantuan dalam mengembangkan hubungan kerjasama dengan agen-agen kemasyarakatan, dan membantu dalam merumuskan kebijakan sekolah yang secara langsung berpengaruh terhadap kesejahteraan anak dan generasi muda.

4. Pekerja sosial harus berkonsultasi dengan para guru tentang teknik-teknik untuk menciptakan iklim di mana anak-anak mereka bebas dan termotivasi untuk belajar. (Sebagai contoh, melalui penafsiran sosial dan pengaruh budaya dan kehidupan siswa, memfasilitasi 
penggunaan teman sebaya untuk menolong anak yang bermasalah, atau membantu dalam aspek lainnya dari seni mengatur hubungan di dalam kelas).

5. Pekerja sosial harus mengorganisir orang tua dan kelompok masyarakat untuk saluran perhatian yang efektif tentang siswa dan sekolah serta bertindak sebagai seorang pembangun kekuatan di dalam hubungan dengan sekolah dan masyarakat.

6. Pekerja sosial harus mengembangkan dan menjaga hubungan yang produktif antara sekolah dan wilayah kritis pekerjaan sosial serta praktek legal supaya memudahkan efektivitas pelayanan masyarakat untuk sekolah anak dan keluarga mereka, membantu dengan perubahan yang direncanakan dalam pola organisasi dari program-program, dan sumber-sumber kesejahteraan sosial, dan bertindak sebagai katalis terhadap agen tersebut dalam masyarakat yang merupakan fungsi utama adalah perubahan pola dari struktur sosial kemasyarakatan (contohnya, kesejahteraan anak, perbaikan kesehatan mental masyarakat, dan pelayanan legal untuk kemiskinan).

7. Akhirnya, pekerja sosial harus menetapkan kepemimpinan dalam koordinasi keahlian multi disiplin ilmu atas nama siswa antara tenaga pelayanan siswa (contohnya, konselor bimbingan, psikolog, perawat, dan petugas pelayanan).

\section{Metode Pekerjaan Sosial Sekolah}

Adapun dalam pelaksanaan metode intervensi pekerjaan sosial yang dibagi ke dalam tiga bagian, yaitu:

1. Intervensi mikro adalah keahlian pekerja sosial untuk mengatasi masalah yang dihadapi individu. Masalah sosial yang ditangani umumnya berkenaan dengan problem psikologis, seperti stress dan depresi, hambatan dengan relasi, penyesuaian diri, kurang percaya diri, keterasingan. Metode yang diterapkan dalam setting ini adalah terapi perseorangan (casework).

2. Intervensi mezzo dalam hal ini keahlian pekerja sosial adalah untuk mengatasi masalah yang dihadapi kelompok. Metode utama yang dilakukan adalah terapi groupwork yang didalamnya melibatkan berbagai teknik pemberian bantuan seperti self help group, dan lainnya.

3. Intervensi makro adalah keahlian untuk mengatasi masalah yang dihadapi komunitas, masyarakat, lingkungannya (sistem sosialnya). (Edi Suharto. 2009. Hlm. 4)

Dalam menjalankan peranya, pekerja sosial memiliki 3 metode yang dilakukan. Pertama adalah pada tingkat mikro, yaitu yang menangani masalah individu, kedua adalah pada tingkat mezzo yang menangani masalah-masalah yang dihadapi sekelompok siswa, dan yang terakhir adalah tingkat makro, pekerja sosial yang menangani masalah yang dialami dalam komunitas.

\section{Penutup}

Pekerja sosial merupakan kegiatan professional yang membantu individu, kelompok atau masyarakat untuk meningkatkan atau memulihkan kemampuan mereka berfungsi sosial. (Adi Fahrudin. 2010. Hlm. 60). Pada praktiknya, pekerja sosial ada di setiap setting kehidupan seperti keluarga, sekolah, industri, rumah sakit, penjara, dan lainnya. Ketidak hadiran profesi ini mengakibatkan permasalahan tidak tuntas. Kurangnya eksistensi mengenai profesi pekerjaan sosial ini pun ikut berpengaruh pada praktik pekerja sosial didalam bidang yang sebenarnya membutuhkan profesi ini.

Perhatian profesi pekerja sosial adalah berfokus pada upaya pemberian bantuan, namun terdapat pula profesi lain yang juga bergerak dalam upaya pemberian bantuan pula (Budhi Wibhawa, dkk. 2010. Hlm. 34). Kemudian muncul pandangan dari masyarakat mengenai pekerja sosial sebagai pekerjaan yang bisa dilakukan oleh setiap orang, sehingga bukan sebuah profesi eksklusif yang harus ditangani dengan sikap profesionalisme. Ditambah lagi belum adanya kepastian hukum yang jelas tentang status pekerja sosial. (diakses di dpr.go.id. 14/10/14 pukul 22:06 WIB). Dengan kondisi ini, 
hal yang harus dilakukan oleh pihak terkait mengenai kejelasan profesi para pekerja sosial adalah mengadakan sosialisasi mengenai peran pekerja sosial kepada pihak yang terkait mengenai penerimaan profesi ini.

\section{Rekomendasi}

Pekerjaan sosial sekolah merupakan bagian dari bidang garapan pekerjaan sosial. Namun eksistensi pekerjaan sosial sekolah di Indonesia belum diakui secara penuh oleh pihak-pihak yang berkepentingan. Oleh karena itu, sangatlah penting bahwa pekerjaan sosial sekolah perlu diakui eksistensinya oleh berbagai pihak yang berkepentingan dengan bidang pekerjaan sosial, utamanya pekerjaan sosial di dunia pendidikan. Peran pekerjaan sosial sekolah merupakan peran srategis yang penting ketika siswa menemui kendala-kendala dalam perkembangan sosialnya di tiga lingkungan kehidupan.

Melalui berbagai perannya di sekolah, pekerja sosial sekolah dapat menjadi tim yang kompeten sesuai dengan bidang tugasnya di sekolah. Pekerja sosial sekolah dapat bekerjasama dengan seluruh staf yang berada di sekolah tempat para pekerja sosial bekerja. Dengan demikian, pekerja sosial sekolah memiliki bidang khusus yang sesuai dengan bidang keahliannya di sekolah yang membedakan dengan profesi lainnya di sekolah

\section{Daftar Pustaka}

Basri, Hasan. 1996. Remaja Berkualitas, Problematika Remaja dan Solusianya. Pustaka Pelajar. Yogyakarta.

Edi Suharto. 2009. Membangun Masyarakat Memberdayakan Masyarakat Kajian Strategis Pembangunan Kesejahteraan Sosial dan Pekerjaan Sosial. PT. Refika Aditama. Bandung Edi Suharto. 2007. Pekerja Sosial di Dunia Industri (Coorporate Social Responsibility). PT. Refika Aditama. Bandung

Fahrudin, Adi. 2012. Pengantar Kesejahteraan Sosial. PT. Refika Aditama. Bandung

Lela B. Costin. 1972. Penyesuaian dalam Penyampaian Pelayanan Pekerjaan Sosial Sekolah. Social Casework.

Sarwono, Sarlito Wirawan. 1993. Psikologi Remaja. Raja Grafinfo Perkasa. Jakarta.

Soetarso. 1993. Praktek Pekerjaan Sosial. Koperasi Mahasiswa Sekolah Tinggi Ilmu Pekerjaan Sosial. Bandung

Sofyan, Willis. 2008. Remaja dan MAsalahnya, Mengupas Berbagai Bentuk Kenakalan Remaja Seperti Narkoba, Free Sex, dan Pemecahannya.

Wibhawa, Budi. Raharjo, T.Santoso. Budiarti. S, Meilany. 2010. Dasar-Dasar Pekerjaan Sosial. Widya Padjadjaran. Bandung. Alfabeta. Bandung. 